УДК 619:616.995.1

doi: 10.36359/scivp.2019-20-2.34

\title{
ОСОБЛИВОСТІ ДЕЗАКАРИЗАЦІЇ В УМОВАХ НАПІВВІЛЬНОГО УТРИМАННЯ КОПИТНИХ
}

С. В. Жигалюк ${ }^{l}$, науковий співробітник,

Р. М. Сачук', канд. вет. наук,

В. О. Пепко ${ }^{2}$, здобувач,

Ю. Р. Гунчак ${ }^{3}$, аспірант,

Я. С. Стравський ${ }^{4}$ д-р вет. наук, с. н. с.,

С. А. Пономарьова ${ }^{5}$, науковий співробітник

${ }^{1}$ Дослідна станція епізоотології Інституту ветеринарної медицини НААН, вул. Князя Володимира, 16/18, м. Рівне, 33028, Україна

${ }^{2}$ Рівненський державний гуманітарний університет, вул. Пластова, 29-а, м. Рівне, 33028, Україна

3 Львівський національний університет ветеринарної медицини та біотехнологій імені. С. 3. Гжицького,

вул. Пекарська 50, м. Львів, 79010, Україна

${ }^{4}$ Тернопільський національний медичний університет імені І. Я. Горбачевського МО3 України, майдан Волі, 1, м. Тернопіль, 46002, Україна

${ }^{5}$ Державний науково-дослідний контрольний інститут ветеринарних препаратів та кормових добавок,

вул. Донецька, 11, 79000, м. Львів, Україна

Викладено результати апробації удосконаленого способу дезакаризаџії диких копитних в умовах напіввільного утримання, щзо включає як обробку тварин, так $i$ санацію місцьь ӥх скупчення новими препаративними композиціями на основі амітразу.

У вольєрному господарстві застосовано сучасні, науково-обтрунтовані, інтегровані підходи до організаиії профілактичних та лікувальних протиектопаразитарних міроприємств. Це дозволило, з мінімальними затратами, без стресового фактору, не знижуючи трофейних властивостей дичини, контролювати чисельність паразитів на відносно безпечному рівні. Спосіб забезпечує самостійну саначію тварин привабливою для них емульсією інсекто-акарициду. При цььому у якості атрактанта, розчинника та репелента використано піддьогтярну воду. Місия підгодівлі тварин оброблено новим інсектоакарицидним препаратом зі знезаражуючим ефектом «Засіб для обробки тваринницьких приміщень «Акаротак Е». Також апробовано індивідуальну терапію новим препаратом івермектинового ряду.

Встановлено високу ефективність застосованих препаратів, зокрема максимальні значення Коефіиієнту захисної дї засобу «Акаротак Д.В.» сягали 76\%. Біологічна ефективність засобу «Акаротак Е» на 1 добу склала - 93,3\% і зберігала високі значення протягом 14 діб.

Ключові слова: КЛІЩІ, ДЕЗАКАРИЗАЦІЯ, КОЕФІЦІЕНТ ЗАХИСТНОЇ ДІЇ, БІОЛОГІЧНА ЕФЕКТИВНІСТЬ.

Ектопаразити, в локальних тваринницьких агроценозах, мають важливе і різноманітне значення. У першу чергу, як злісні кровососи та збудники нашкірних дерматитів, а також як 
агенти алергічних захворювань, шкідники хутра, проміжні господарі ряду гельмінтів, переносники збудників заразних хвороб тварин i людини. В умовах тваринницьких господарств виявлено десятки паразитичних, зоофільних чи синантропних видів і сотні видів супутньої фауни безхребетних [2]. Особливо помітним є значення паразитиформних кліщів, шкодочинність яких також має подвійну природу: як переносників більше 50 нозологічних одиниць трансмісивних інфекцій, так і власне як паразитів-кровососів. Також суттєвим для ценозу є наявність акариформних кліщів, які крім згаданого $є$ ще шкідниками кормів, деструкторами органічних решток та беруть участь у контамінації середовища перебування спорами пліснявих грибків.

Основою ефективного і прибуткового тваринництва $є$ епізоотичне благополуччя поголів 'я, яке досягається регулярними, науково-обгрунтованими протипаразитарними заходами. Паразитофауна сільськогосподарських та диких копитних виділяється значним таксономічним і видовим біорізноманіттям, а це потребує інтегрованих підходів до контролю їх чисельності.

Колекційний матеріал, зібраний лабораторією паразитології, включає 18 видів кліщів (гамазиди - 13, іксодиди - 5), виявлених на території тваринницьких господарств регіону. Згідно діючих нормативів, 3 метою дезакаризації, проводять загально-санітарні заходи, вимушені акарицидні обробки приміщень (ферм) та «шкірний покрив великої рогатої худоби обробляють препаратами інсектоакарицидної і репелентної дії в порядку, передбаченому спеціальними інструкціями» [10].

Особливо складною є лікувальна дезакаризація диких копитних.

Мета роботи полягала у вивченні місцевої акарофауни і апробації, розроблених на основі отриманих знань, нових підходів до дезакаризації диких копитних в умовах діючого вольєра та вивчення біологічної ефективності нових препаратів і форм.

Матеріали та методи. Дослідна робота проведена на базі вольєру для диких копитних МСК «Сокіл» Рівненської області. Апробовано три способи проведення протиектопаразитарних міроприємств: профілактична дезакаризація за допомогою чесальних стовпів, санація біоцидом місць підгодівлі і вигульних майданчиків та індивідуальна хіміотерапія новим препаратом івермектинового ряду.

Вираховували коефіцієнт захисної дії та біологічну ефективність препаратів:

$$
\begin{aligned}
& \text { КЗД }=100-\frac{\mathrm{A} \times \mathrm{B}_{1}}{\mathrm{~B} \times \mathrm{A}_{1}} \times 100 \quad \text {, де } \mathrm{A} \text { і В - число кліщів відповідно на обробленій і контрольній } \\
& \mathrm{C}=100 \times\left(1-\mathrm{B}_{2} \Gamma_{1} / \mathrm{B}_{1} \Gamma_{2}\right) \text {, де } \mathrm{B}_{1} \Gamma_{1} \text { - кількість живих особин у досліді і контролі до обробки; } \\
& \mathrm{B}_{2} \Gamma_{2} \text { - кількість живих особин у досліді і контролі після обробки. }
\end{aligned}
$$

Для обліку вибірково використовували по 6 тварин у досліді і контролі. Обліки чисельності іксодид на тваринах здійснювали за допомогою розробленого нами способу, суть якого полягає у отриманні цифрових одномоментних знімків усіх ділянок тіла тварини (передньої і задньої частин тіла, передніх і задніх кінцівок), з подальшим підрахунком кліщів на моніторі, покадрово, у збільшеному форматі [1]. Фотофіксація через 2, 4, 24, 36 год.

Забір проб субстратів для пошуку мезостигмат здійснювали у 4 контрольних точках, через 2, 6, 10, 24 год; 2, 7, 14 діб, за стандартними методиками [5,9].Вивільнення кліщів шляхом термоеклектування. Облік шляхом візуальних підрахунків. Також досліджено вміст 22 гніздово-нірних зборів та обстежено тушки 48 дрібних хребетних.

Результати й обговорення. Протягом трирічних обстежень визначено 39 видів акарид, що належать до 14 родин рядів Acariformes i Parasitiformes. Виявлені на обстеженій території кліщі - постійні співчлени агроценозів, нами умовно розділені на біоекологічні групи 3 наступним співвідношенням показників чисельності, у процентах:

1. Постійні, видоспецифічні паразити $-2,5 \%$; 
2. Факультативні, паразити теплокровних - $11 \%$;

3. Кліщі-хижаки та паразити членистоногих $-7,5 \%$;

4. Акаридієві кліщі-поліфаги - 56,3\%;

5. Сапрофаги-деструктори органічних решток - 18,5\%;

6 . Види з невизначеними статусом $-4,2 \%$.

Стаціально домінуює мезофауна фекально-підстилочних мас та акаридії у залишках кормових мас.

На обстеженій території виявлено:

- іксодиди: Ixodes ricinus L., 1758 (ІД-89,6), Dermacentor reticulatus Hermann, 1804 (ІД10,4). Стаціальний розподіл: у біотопі - 40,0 \%, на основних живителях - 42,9 \%; на другорядних - 17,1 \% (у т. ч. лісова полівка (КП- 4,7 \%), кріт (КП- 2,5\%), миша мала (КП1,5 \%), синантропні птахи (КП- 0,5 \%); німфи - щур (КП- 7,9 \%).

- гамазові та акаридісві кліщі, EI- 78\%. IIc-106. Домінують: Acarus siro L.,1758, (IД55,2); Glyciphagus domesticus De Geer, 1778, (ІД-11,2); Allodermanyssus sanguineus Hirst, 1914, (ІД-5,3).

Дезакаризація копитних має ряд особливостей, організаційних і методичних. Піки нападів іксодид, наприклад, припадають на пасовищний сезон. За вільного випасу ВРХ, групова санація інсекто-акарицидами для зовнішнього застосування $є$ проблематичною. Крупні, норовливі тварини неохоче піддаються і вимушеним індивідуальним обробкам. Особливо складно провести дезакаризацію диких копитних: тварин необхідно вистежити, спіймати, знерухомити, що є стресовим фактором для тварин, та потребує значних зусиль. Для продуктивних тварин є обмеження по складу препаратів і термінах їх каренції. Має суттєве значення частота обробок і тривалість репелентної дії засобу.

Поширеними є способи індивідуального застосування ін`єкцій (макроциклічних лактонів), або інсекто-акарицидів (піретроїди, ФОСи, амідини) з різноманітним складом діючих речовин наступними способами:

- «спот-он» - нанесення на шкіру холки крапельним методом;

- застосування кліпс, бірок, ошийників з препаратами;

- застосування пудр і дустів з отрутохімікатами;

- застосування препаратів у формі аерозолів;

- застосування водних розчинів у вигляді лікувальних ванн.

Дані способи мають обмеження за видами тварин (лактони), відрізняються вартістю (перші більш затратні) та термінами захисної дії (менші у пудр та аерозолів). Недоліком застосування кліпс та бірок $є$ нижча концентрація вивільнених діючих речовин, тому хороший ефект досягається переважно «колективним захистом», коли тварини випасаються на обмеженій спільній території. Найбільш суттєвими недоліками цих способів є значна трудомісткість, тривалий час виконання і стресовість для тварин.

Відповідно, пошук доступних засобів і практичних методів боротьби 3 кліщами $\epsilon$ актуальним. Нами за основу взято спосіб, рекомендований для диких копитних, коли використовується сукно просякнуте дьогтем та інсекто-акарицидними препаратами [7].

Підмічено, що дьогтьова основа є привабливою для тварин. Дьоготь березовий широко використовується при лікуванні ряду захворювань тварин. Дьоготь - сильний бактерицидний засіб, у формі лініментів і емульсій згубно діє на вошей, бліх, кліщів. Використовується як відхаркувальний и знезаражуючий засіб. Масляний розчин дьогтю може застосовуватися для захисту тварин на випасі від кровосисних комах - комарів, мух, мошок.

Перевагою цього способу є зручність застосування. Суттєвим недоліком - зниження трофейних якостей дичини, через знецінення шкіри: дьоготь викликає злипання волосяного покриву, що веде до інтенсивного розчісування у місцях нанесення. Крім того, є проблема підбору препаратів, що розчиняються у дьогті. 
Для запобігання проблемам у місцях нанесення нами запропоновано, у якості атрактанта для копитних, розчинника для біоциду та репелента для кліщів, використати піддьогтярну воду. Як інсекто-акарицидний засіб використано амітраз.

Піддьогтярна вода - побічний продукт виробництва дьогтю березового. За технології сухої перегонки березової берести, крім основного продукту - дьогтю, отримують $25 \%$ піддьогтярної (підсмольної) води, яка за запахом не відрізняється від дьогтю, тобто, для копитних, має ефект атрактанту. За даними Ф. А. Таланіна, піддьогтярна вода містить 2-3 \% оцтової та мурашиної кислот та до 0,8 \% метилового спирту [8], чим підсилюється репелентна дія суміші.

Амітраз (тактик) - 1,4-ди-(2,4-диметилфеніл)-3-метил-1,3,5-триазапента-1,4-діен органічна сполука синтетичного походження, групи амідинів випускається рядом закордонних фірм ("Шерінг", "Хехст", Германія; Інтервет, Франція). Використовується в рослинництві, тваринництві та бджільництві як ефективний акарицид системної дії. Активний також проти ряду комах, у тому числі паразитів тварин. $€$ обмежено токсичним для теплокровних тварин. Немає обмежень у застосуванні лактуючим тваринам. Володіє кишковою і контактною дією відносно паразитів [3]. Застосовується зовнішньо, шляхом нанесення на шкіру та у вигляді ванн.

Сам спосіб дезакаризації виконано наступним чином. У місцях підгодівлі тварин встановили 3 похилі «чесальні стовпи» навкруг обтягнені войлоком до 2 см завтовшки, які обробили експериментальним препаратом «Акаротак Д.В.» (емульсія підьогтярної води i 0,025 \% амітразу). Привабливість композиції для копитних, забезпечує самостійну їх санацію, що вирішує питання доступу до тварини у напіввільних умовах і має мінімальний вплив на середовище. Форма і розмір дерев яної основи підбирається залежно від виду копитних. Можливе застосування інших, дозволених до використання в Україні інсекто-акарицидних препаратів, наприклад 0,05 \% неоцидолу. Термін оновлення робочої рідини на встановлених спорудах залежить від інтенсивності нападів паразитів, але не рідше ніж 1 раз на 7 днів.

Протягом періоду спостереження встановлено значну привабливість для тварин запропонованої суміші «Акаротак Д.В.»: усі тварини підходять до чесальних стовпів для тривалої санації. Чесальні стовпи видалили з вольєру за 6 годин.

Активні елементарні поведінкові рухи кліщів розпочалися одразу, кліщі мігрували від оброблених (вичуханих) місць. За дві години спостерігався високий ефект, КЗД у середньому становив 73,4 \% у межах від 66,7 до 76,0 \%. За добу відлякувальна дія препарату почала поступово послаблюватися. КЗД коливався в межах від 62,5 до 75,0 \% із середнім показником 68,9 \%. На 3 добу КЗД знизився до 52,9 \% (табл. 1.).

Таблиия 1

Динаміка КЗД «Акаротак Д.В.»

\begin{tabular}{|c|c|c|c|c|c|c|c|c|c|c|c|c|c|c|c|c|c|c|}
\hline \multirow{2}{*}{$\begin{array}{c}\text { Ділянки локалізації } \\
\text { на тварині }\end{array}$} & \multicolumn{6}{|c|}{ Контроль (не оброблялися) } & \multicolumn{6}{|c|}{ Дослід (4 год) } & \multicolumn{6}{|c|}{ Дослід (24 год) } \\
\hline & 1 & 2 & 3 & 4 & 5 & 6 & 1 & 2 & 3 & 4 & 5 & 6 & 1 & 2 & 3 & 4 & 5 & 6 \\
\hline Передня кінцівка & 15 & 9 & 12 & 8 & 10 & 11 & 5 & 4 & 6 & 2 & 3 & 5 & 3 & 2 & 3 & 2 & 5 & 3 \\
\hline Задня кінцівка & 6 & 5 & 8 & 4 & 7 & 6 & 3 & - & 2 & 1 & - & - & 2 & 1 & 1 & 1 & 2 & 2 \\
\hline Перед. частина тіла & 8 & 9 & 6 & 6 & 4 & 7 & 2 & 2 & 1 & 2 & 3 & 1 & 1 & 2 & 1 & 2 & 1 & 1 \\
\hline Задня частина тіла & 4 & 4 & 5 & 4 & 4 & 4 & 1 & 1 & - & - & - & 1 & 1 & 1 & - & 1 & 1 & 1 \\
\hline Всього & 33 & 27 & 31 & 22 & 25 & 28 & 11 & 7 & 9 & 5 & 6 & 7 & 7 & 6 & 5 & 6 & 9 & 7 \\
\hline КЗД, \% & & & & & & & 66.7 & 74.1 & 70.9 & 77.3 & 76 & 75 & 73.1 & 66.7 & 75.0 & 62.5 & 64.0 & 72.0 \\
\hline
\end{tabular}

За відсутності копитних місця підгодівлі, годівниці та інвентар оброблено емульсією експериментального препарату «Засіб для обробки тваринницьких приміщень «Акаротак Е», у якому інсекто-акарицидна речовина - амітраз (1\%), у поєднанні з органічним розчинником диметилсульфоксидом і неіоногенною ПАР, розведена у водному розчині органічного дезінфектанта - полігексаметиленгуанідину гідрохлориду. 
Диметилсульфоксид (ДМСО) - засіб для місцевого застосування. Має здатність проникати крізь біологічні мембрани, включаючи бар'єри шкіри, реалізуючи таким чином свої специфічні ефекти. Підсилює проникнення лікарських засобів крізь шкірні покриви і слизові оболонки (здатність до транспортування) [4].

Неіоногенна поверхнево активна речовина (ПАР) Синтамід-5К - суміш поліоксиетильованих ефірів моноетаноламідів жирних кислот кокосового масла фракції С7C17. Підсилює явище змочування поверхні, чим сприяє кращому контакту засобу з шкірними покривами членистоногого на початку обробки.

Полігексаметиленгуанідину гідрохлорид (ПГМГ) є одним з найбільш ефективних i безпечних дезінфікуючих засобів [6]. Наявність у його молекулі полярної гуанідинової і неполярної гексаметиленової груп забезпечує йому властивості адгезива та поверхневоактивної речовини. Бактерицидна дія обумовлена здатністю похідних гуанідину зв'язуватися 3 клітинними стінками та мембранами бактерій, проникати всередину клітини та інгібувати клітинні ферменти. Препарати ПГМГ ефективні по відношенню до вегетативних форм бактерій, багатьох грибів та оболонкових вірусів.

Усі компоненти препарату водорозчинні. Робочий розчин препарату, отримано розведенням концентрату у 5 разів, безпосередньо перед застосуванням. Оброблено 3 розрахунку 10 л розчину на $1000 \mathrm{M}^{2}$, що досягається розпиленням за тиску Затм. і швидкості виходу з сопла розпилювача $21 \mathrm{мл/с} 3$ використанням центробіжної форсунки.

Під час контакту емульсії з членистоногим хітинова оболонка, проявляючи гідрофільні властивості, притягує ДМСО з амітразом і завдяки своїй проникаючій здатності ДМСО швидко проводить біоцид через хітин, вражаючи нервову систему кліща. А ПАВ дозволяє препарату повністю локалізуватися на поверхні кліща. При цьому піддаються впливу яйця і ювенільні форми.

Після висихання робочого розчину на обробленій поверхні утворюється тонка прозора полімерна плівка, яка забезпечує тривалу антисептичну і інсекто-акарицидну дію та запобігає випаровуванню акарициду, внаслідок чого періодична обробка поверхні розчином препарату може проводитись через більш тривалий проміжок часу, ніж при застосуванні більшості інших біоцидних засобів.

Біологічна ефективність препарату на 1 добу склала - 93,3 \%. У місцях обробки задовільний ефект від застосування зберігається протягом 7 діб - 80,9 \%, а на 14 добу біологічна ефективність препарату склала 71,9 \% (табл. 2).

Таблиия 2

Середня чисельність акарид у пробі при апробації препарату «Акаротак Е»

\begin{tabular}{|c|c|c|c|c|c|c|c|}
\hline \multirow{2}{*}{ Акаротак Е } & \multicolumn{4}{|c|}{ Експозиція, год/ $\mathrm{c}$. екз. } & \multicolumn{3}{c|}{ Експозиція, діб/ $\mathrm{c}$. екз. } \\
\cline { 2 - 8 } & 2 & 6 & 10 & 24 & 2 & 7 & 14 \\
\hline Дослід 1 & 37 & 60 & 7 & 1 & 0 & 9 & 11 \\
\hline Контроль 1 & 110 & 98 & 101 & 97 & 107 & 121 & 92 \\
\hline
\end{tabular}

Додатково, у двох випадках, на вимогу власників вольєру, проведено акарологічне обстеження самців муфлона європейського (Ovis ammon musimon L.1758), 3 клінічними ознаками нашкірного паразитозу. Мікроскопія зіскобів встановила наявність Psoroptes sp. Тварин карантинізували. Застосовано підшкірні ін`єкції препарату «Девімектин 1\%», виробництва ТОВ «ДЕВIЕ», 3 розрахунку 0,5 мл на кожні 25 кг ваги тварини. За 10 діб обробку повторили. За 15 діб тварин повернули до вольєру без клінічних ознак інвазії.

\section{В И С Н О В К И}

1. Апробовано три способи проведення протиектопаразитарних заходів: лікувальнопрофілактичну дезакаризацію за допомогою «чесальних стовпів», санацію місць підгодівлі і 
вигульних майданчиків і індивідуальну хіміотерапію новим препаратом івермектинового ряду. Удосконалений спосіб дезакаризації копитних за допомогою «чесальних стовпів» оброблених відлякувально-лікувальною сумішшю, включає самостійну санацію тварин привабливою для них емульсією інсекто-акарициду i відрізняється використанням піддьогтярної води у якості атрактанта, розчинника та репелента.

2. Встановлено високу ефективність застосованих препаратів, зокрема максимальні значення Коефіцієнту захисної дії засобу «Акаротак Д.В» сягали 76\%. Біологічна ефективність засобу «Акаротак Е» на 1 добу склала - 93,3 \% і зберігала високі значення протягом 14 діб. Це дозволяє, з мінімальними затратами, без стресового фактору, не знижуючи трофейних властивостей дичини, контролювати чисельність паразитів на відносно безпечному рівні.

Перспективи досліджень. Подальші дослідження будуть направлені на апробацію і впровадження аналогічних методичних підходів для санації ВРХ, підчас пасовищного сезону.

\title{
FEATURES OF DEZAKARIZATION IN THE CONDITIONS OF SUCCESSFUL SUPPORT OF COSTS
}

\author{
S. V. Zhyhalyuk ${ }^{1}$, R. M. Sachuk ${ }^{1}$, V. O. Pepko², Yu.R. Gunchak ${ }^{3}$, \\ Ya. S. Stravskyi ${ }^{4}$, S. A. Ponomarjova ${ }^{5}$ \\ ${ }^{1}$ Research Epizootology Station IVM NAAS \\ 16/18, Knyazya Volodymyra str., Rivne, 33028, Ukraine \\ ${ }^{2}$ Rivne State Humanitarian University, \\ 29-a, Plastova str., Rivne, 33028, Ukraine.
}

${ }^{3}$ Stepan Gzhytskyi National University of Veterinary Medicine and Biotechnologies 50, Pekarska str., 79010, Lviv, Ukraine

${ }^{4}$ Ternopil State Medical University named after Gorbachevsky Ministry of Health of Ukraine, 1, maydan Voli, Ternopil', 46002, Ukraine

${ }^{5}$ State Scientific-Research Control Institute for Veterinary Medicinal Products and Feed Additives, 11, Donetska, str., 79000, Lviv, Ukraine

\section{S U M M A R Y}

The results of approbation of the improved method of dezakarization of wild ungulates in conditions of semi-free maintenance containing both animal treatment and the rehabilitation of places of their accumulation with new amitraze-based preparative compositions are described.

The entrances have applied modern, scientifically-based, integrated approaches to the organization of preventive and therapeutic anti-parasitic measures. This allowed, with minimal cost, without the stress factor, without reducing the trophy properties of the game, to control the number of parasites at a relatively safe level. The method provides an independent sanation of animals attractive to them by the emulsion of insecto-acaricide. In this case, as an attractant, solvent and repellent, used water is used. Places for feeding animals were treated with a new insecto-acaricidal preparation with a disinfectant effect "Acarotak E" for livestock processing. Also, individual therapy with the new drug ivermectin series has been tested.

The high efficiency of the applied drugs, in particular the maximum values, was established. The protective factor of the "Acarotak D.V." agent reached $76 \%$. The biological efficiency of the "Acarotak E" agent for 1 day amounted to 93,3\% and remained high for 14 days.

Key words: CLOSE, DEZAKARIZATION, COEFFICIENT OF PROTECTIVE ACTION, BIOLOGICAL EFFICIENCY. 


\title{
ОСОБЕННОСТИ ДЕЗАКАРИЗАЦИИ В УСЛОВИЯХ ПОЛУСВОБОДНОГО СОДЕРЖАНИЯ КОПЫТНЫХ
}

\author{
С. В. Жигалюк, Р. М. Сачук, В. О. Пепко ${ }^{2}$ Ю. Р. Гунчак ${ }^{3}$, \\ Я. С. Стравський, С. А. Пономарева \\ ${ }^{1}$ Опытная станция эпизоотологии ИВМ НААН, \\ ул. Князя Владимира, 16/18, г. Ровно, 33028, Украина \\ ${ }^{2}$ Ровенский государственный гуманитарный университет, \\ ул. Пластовая, 29-а., г. Ровно, 33028, Украина
}

${ }^{3}$ Львовский национальный университет ветеринарной медицины и биотехнологий им. С. 3. Гжицкого, ул. Пекарская, 50, г. Львов, 79010, Украина

${ }^{4}$ Тернопольский национальный медицинский университет имени И. Я. Горбачевского MO3 Украины, площадь Свободы, 1, г. Тернополь, 46002, Украина

${ }^{5}$ Государственный научно-исследовательский контрольный институт ветеринарных препаратов и кормовых добавок, ул. Донецкая, 11, 79000, г. Львов, Украина

\section{А Н Н О Т А ЦИЯ}

Изложены результаты апробации усовершенствованного способа дезакаризации диких копытных в условиях полусвободного содержания, включющие как обработку животных, так и санацию мест их скопления новыми препаративными композициями на основе амитраза.

В вольерном хозяйстве применены современные, научно-обоснованные, интегрированные подходы к организации профилактических и лечебных противоэктопаразитарных мероприятий. Это позволило, с минимальными затратами, без стрессового фактора, не снижая трофейных качеств дичи, контролировать численность паразитов на относительно безопасном уровне. Способ обеспечивает самостоятельную санацию животных привлекательной для них эмульсией инсекто-акарицида. При этом в качестве аттрактанта, растворителя и репеллента использовано поддегтярную воду. Места подкормки животных обработано новым инсекто-акарицидным препаратом с обеззараживающими свойствами «Средство для обработки животноводческих помещений «Акаротак Е». Также апробировано индивидуальную терапию новым препаратом ивермектинового ряда.

Установлена высокая эффективность примененных препаратов, в частности максимальные значения Коэффициента защитного действия средства «Акаротак Д.В.» достигали 76 \%. Биологическая эффективность средства «Акаротак Е» на 1 сутки составила 93,3 \% и сохраняла высокие значения в течение 14 суток.

Ключевые слова: КЛЕЩИ, ДЕЗАКАРИЗАЦИЯ, КОЭФФИЦИЕНТ ЗАЩИТНОГО ДЕЙСТВИЯ, БИОЛОГИЧЕСКАЯ ЭФФЕКТИВНОСТЬ.

\section{Л I T E P A T Y P A}

1. Патент України на корисну модель № 69220 «Спосіб обліку чисельності кровосисних двокрилих комах на тварині за допомогою цифрової фотокамери» / Катюха С.М.; заявник і патентовласник Інститут епізоотології НААН; заяв.26.09.2011; опубл. 25.04.2012, Бюл. № 8.

2. Абуладзе К. И. Паразитология и инвазионные болезни сельскохозяйственных животных / К. И. Абуладзе, С. Н.Никольский, Н. А.Колабский. - М.: Колос, 1975. - 471 с. 
3. Бирюков A. А. Санитарно-токсикологическая оценка Амитраза как средства борьбы с демодекозом собак: автореф. дис. на соискание уч. степени канд. вет. наук: спец. 16.00.06 «Ветеринарная санитария и экология» / А. А. Бирюков. - М., 1998. - 23 с.

4. Бойко H. Н. Влияние различных концентраций и сочетаний растворов димексида на течение раневого процесса / Н. Н. Бойко // Клиническая хирургия. - 1979. - №1 - С.64-65.

5. Бэкер Э., Уартон Г. Введение в акарологию // М.: И.*Л., 1955.

6. Гембицкий П. А. Полимерный биоцидный препарат полигексаметиленгуанидин / П. А. Гембицкий, И. И. Воинцева. - Запорожье: Полиграф, 1998. - 44 с.

7. Мануйлова О. Рекомендации по противопаразитарным работам для копытних/ О.Мануйлова // Охота - национальный охотничий журнал. - 2012.-№9(54). - C.44-47.

8. Таланин Ф. А. Производство берестового дегтя / Ф.А. Таланин. - М.: Лесная промышленость, 1981. - 72 с.

9. Фасулати К. К. Полевое изучение наземных безпозвоночных // "Высшая школа". M.,1971.

10. Ветеринарна дезінфекція, дезодорація, дезінсекція, дезінвазія, дератизація / О. М. Якубчак, В. І. Хоменко, С. В. Мідик та ін. - К.: НАУ, 2005. - 75 с. - [Нормативний документ Держдепартаменту ветеринарної медицини. Інструкція.

\section{References}

1. Katiukha S. M. (2012). Patent Ukrainy na korysnu model № 69220 «Sposib obliku chyselnosti krovosysnykh dvokrylykh komakh na tvaryni za dopomohoiu tsyfrovoi fotokamery» Biul. № 8. (in Ukrainian).

2. Abuladze K. Y., Nykolskyi S. N., \& Kolabskyi N. A. (1975). Parazytolohyia i invazionnue bolezni selskokhoziaistvennuh zhyvotnuh. M.: Kolos. (in Russian).

3. Byriukov A. A. (1998). Sanytarno-toksykolohycheskaia otsenka Amytraza kak sredstva borbu s demodekozom sobak: avtoref. dys. na soyskanye uch. stepeny kand. vet. nauk: spets. 16.00.06 «Veterynarnaia sanytaryia i ekolohyia». M. 23 s. (in Russian).

4. Boiko N. N. (1979) Vlyianye razlychnukh kontsentratsyi i sochetanyi rastvorov dymeksyda na techenye ranevoho protsessa. Klynycheskaia khyrurhyia. 1, 64-65. (in Ukrainian).

5. Beker E., Uarton H. (1955). Vvedenye v akarolohyiu. M.: Y.*L. (in Russian).

6. Hembytskyi P. A., Voyntseva Y. Y. (1998). Polymernui byotsydnui preparat polyheksametylenhuanydyn. Zaporozhe: Polyhraf, 44. (in Ukrainian).

7. Manuilova O. (2012) Rekomendatsyy po protyvoparazytarnum rabotam dlia koputnykh. Okhota - natsyonalnui okhotnychyi zhurnal. 9(54), 44-47. (in Russian).

8. Talanyn F.A. (1981). Proyzvodstvo berestovoho dehtia M.: Lesnaia promushlenost. $72 \mathrm{~s}$. (in Russian).

9. Fasulaty K.K. (1971). Polevoe yzuchenye nazemnukh bezpozvonochnukh. "Vusshaia shkola". M. (in Russian).

10. Yakubchak O.M., Khomenko V.I., \& Midyk S.V. (2005). Veterynarna dezinfektsiia, dezodoratsiia, dezinsektsiia, dezinvaziia, deratyzatsiia. K.: NAU. 75 s. [Normatyvnyi dokument Derzhdepartamentu veterynarnoi medytsyny. Instruktsiia.]. (in Ukrainian).

Рецензент - А. В. Лисиця, д. б. н., доцент, Дослідна станція епізоотології IВМ НААН. 